\title{
New records of pontoniine shrimp genus Onycocaris Nobili, 1904 (Crustacea: Decapoda: Palaemonidae) from the Indo-Pacific with the description of two new species from French Polynesia
}

\section{Новые находки креветок-понтонии рода Onycocaris Nobili, 1904 (Crustacea: Decapoda: Palaemonidae) из Индо-Пацифики с описанием двух новых видов из Франщузской Полинезии}

\author{
Ivan N. Marin \\ И.Н. Марин
}

\begin{abstract}
A.N. Severtzov Institute of Ecology and Evolution of RAS, Leninsky prisp., 33, Moscow 119071, Russia. E-mail: coralliodecapoda@mail.ru, vanomarin@yahoo.com

Институт проблем экологии и эволюции им. А.Н. Северцова РАН, Ленинский просп., 33, Москва 119071, Россия. E-mail: coralliodecapoda@mail.ru, vanomarin@yahoo.com
\end{abstract}

KEY WORDS: Crustacea, Decapoda, Caridea, Palaemonidae, Pontoniinae, Onycocaris, new species, new records, association, sponge, Moorea, French Polynesia, Japan, Australia.

КЛЮЧЕВЫЕ СЛОВА: Crustacea, Decapoda, Caridea, Palaemonidae, Pontoniinae, Onycocaris, новые виды, новые находки, ассоциации, губки, Муреа, Французская Полинезия, Япония, Австралия.

ABSTRACT. Several new species and records of representatives of the genus Onycocaris from IndoPacific are presented in the paper. A local diversity of Onycocaris species is studied for Moorea, French Polynesia, based on a collection of University of Florida, Gainesville, FL, USA. As a result, four Onycocaris species are recorded from Moorea including two species (Onycocaris zarenkovi sp.n. and Onycocaris rudolfi sp.n.) described as new to science. Additionally, a specimen of $O$. spinosa is described from Australia and several specimens of $O$. callyspongia are described from Chiba Peninsula of Honsu Island, Japan. Discussion on differential morphological features of new species as well as separation of several species groups within the genus are presented. A renewed identification key for "Onycocaris profunda-species group" is presented.

РЕЗЮМЕ. В статье представлены несколько новых находок, а также описания новых видов креветок из рода Onycocaris из Индо-Пацифики. На основе коллекции Университета Флориды (Гейнсвилл, Флорида, США) исследовано локальное разнообразие данного видов рода в районе о-ва Муреа, Французская Полинезия. В результате обнаружено четыре вида, в том числе два вида новых для науки (Onycocaris zarenkovi sp.n. и Onycocaris rudolfi sp.n.), описания которых приводятся в данной статье. Кроме того, один экземпляр O. spinosa из коллекции Университета Флориды описан из Австралии и несколько экземпляров $O$. callyspongia описаны из вод, омывающих п-ов Чиба (Хонсю, Япония), на основе собственных сборов автора. В работе при- водятся обсуждение отличительных морфологических признаков для новых видов, а также дифференциация нескольких видовых групп внутри рода Onycocaris. Представлен обновленный определительный ключ для группы видов “Onycocaris profunda".

\section{Introduction}

The sponge-associated pontoniine shrimp genus $\mathrm{On}$ ycocaris Nobili, 1904 presently includes 20 valid species: Onycocaris aualitica (Nobili, 1904), O. quadratophthalma (Balss, 1921), O. amakusensis Fujino et Miyake, 1969, O. callyspongiae Fujino et Miyake, 1969, O. oligodentata Fujino et Miyake, 1969, O. spinosa Fujino et Miyake, 1969, O. zanzibarica Bruce, 1971, O. seychellensis Bruce, 1971, O. trullata Bruce, 1978, O. furculata Bruce, 1979, O. longirostris Bruce, 1980, O. profunda Bruce, 1985, O. bocki Bruce, 1992, O. stradbrokei Bruce, 1998, O. temiri Marin, 2005, O. nieli Bruce, 2011, O. balssi Bruce, 2011, O. fujinoi Bruce, 2011, O. hayamaensis Komai et Itou, 2012, and O. maui Bruce, 2013. A key to all known species is presented by Bruce [2011a]. Because of relatively rare findings of these shrimps, some species are known by a single specimen and poorly described as well as complexes of sibling species are also present [Bruce, 2011a, b].

All known Onycocaris species are known living in heterosexual pairs inside internal cavities of sponges. Obviously the sponge fauna is very rich in most of tropical Indo-Pacific localities as well as local diversity of symbiotic faunas including the species diversity of the genus Onycocaris is far to be well studied. Most 
presently diverse area are the one of the Great Barrier Reef of Australia with 8 Onycocaris species known [review in Bruce, 2011a, 2012], and the one of Japan with 7 known species [Fujino, Miyake, 1969; Hayashi, 2003; Bruce 2011a, b; Komai, Itou, 2012], while only few species are known from most of other localities. For example, only two Onycocaris species are presently known from Vietnam [Marin, Savinkin, 2007; Marin, 2012] where the fauna of sponge-associates has been studied for a long time [Marin, 2005, 2007, 2012; Anker et al., 2006; Dworschak, 2006; Anker, Marin, 2006, 2007; Marin, Savinkin, 2007; Duriš et al., 2008].

During the study of the pontoniine shrimp collection deposited in the University of Florida, Gainesville, FL, USA (UF), a small collection from Moorea, French Polynesia was examined. As a result four Onycocaris species are reported from Moorea including two species new to science described herewith. Additionally, a specimen of rare species $O$. spinos $a$ is described from the Great Barrier Reef of Australia and several specimens of $O$. callyspongia, personally collected by the author, are described from Chiba Peninsula of Honsu Island, Japan. Postorbital carapace length (pcl., in mm) is used as a standard measurement of the size. The type material is deposited in the University of Florida, Gainesville, FL, USA (UF) and the Laboratory of Ecology and Morphology of Marine Invertebrates (LEMMI) of the A.N. Severtzov Institute of Ecology and Evolution of Russian Academy of Sciences, Moscow, Russia. Only primary synonyms are given.

\section{Taxonomy}

Order Decapoda Latreille, 1803

Family Palaemonidae Rafinesque, 1815

Subfamily Pontoniinae Kingsley, 1878

Genus Onycocaris Nobili, 1904

Onycocaris callyspongiae Fujino et Miyake, 1969 Figs 1a, 2, 3. $10-12$

Onycocaris callyspongiae Fujino, Miyake, 1969: 422, figs.

MATERIAL EXAMINED. 1 ovigerous female (pcl $1.7 \mathrm{~mm}$ ), BIZ 266, Pacific Ocean, French Polynesia, Moorea, N of Motu Ahe, off MPA post, fore reef, rubble sweat, 30-35 m, coll. Chris Meyer, 9.12.2009; 2 ovigerous females (pcl. 5.0, 5.2 mm), 1 male (pcl. $4.8 \mathrm{~mm}$ ), LEMMI, Pacific Ocean, Japan, Honsu Island, Chiba Peninsula, small fishing port near Ubara City, extracted from large sponges Callyspongia sp. collected from nets of fisherman, coll. I. Marin, 21-22.09.2009.

DIAGNOSIS. Small-sized species with subcylindrical body (Fig. 1a). Carapace smooth, swollen, with distally produced inferior triangular orbital angle; antennal tooth absent (Figs 2a,b). Rostrum short, compressed, not reaching the middle of eyestalk, with tip slightly turned upward, with deep unarmed dorsal lamina, with feebly developed ventral lamina, lateral lamina well developed along all length of the rostrum (Fig. $2 a, b)$, proximal lateral rostral lamina feebly developed (Fig. 2b); orbit feebly developed, pterygostomial angle rounded. Abdominal somites smooth; pleurae of abdominal somites I-V rounded (Fig. 1a). Telson (Fig. $2 h$ ) stout, about 1.5 times as long as proximal width, narrowing distally, with 2 pairs of small dorsal marginal spines at 0.4 and 0.6 of telson length; distal margin of telson armed with 3 pairs of spines. Eyes (Figs $2 c-e$ ) stout, with reduced suboval cornea and flattened stout eyestalk, without lateral depression. Antennule (Fig. $2 f$, g) slightly reduced, compressed; basicerite with distolateral angle unarmed, without submarginal ventral tooth. Antenna normal, with basicerite unarmed, with long slender carpocerite and well developed wide scaphocerite bearing well marked distolateral tooth. Mouthparts normal, characteristic for the genus. Pereiopod I (Fig. 3a) with slender segments; palm about 3 times longer than fingers; dactylus and fixed finger simple, with entire cutting margins, with simple tips. Pereiopods II similar in shape and slightly unequal in size (Figs 3b, c); major pereiopod II (Fig. 3b) with stout segments, ischium stout, with several small notches along ventral and dorsal margins, with large distolateral tooth; merus swollen in medial part, with 2 medial notches dorsally; carpus triangular, not overlapping carpo-propodal articulation, with bluntly produced distodorsal margin; propodus compressed, about as long as wide, with small tubercles on medial part of ventral margin; fingers (Figs $3 f, g$ ) relatively stout, cutting margin with 2 large triangular teeth; fixed finger with 3-4 small blunt submarginal triangular teeth along inner margin, dactylus without such teeth; minor pereiopod II (Fig. 3c) generally similar to major (Fig. $3 b$ ), slightly smaller in size, with 5-6 tubercle-like small submarginal teeth along cutting edges of both, fixed finger and dactylus with small blunt submarginal triangular teeth along inner margin (Fig. $3 d, e$ ). Pereiopod III stout; propodus with straight lateral margins, with 2 single spines situated in distal part of ventral margin and a pair of slender spines at the distoventral angle; dactylus stout, biunguiculate, ventral margin armed with 5 large triangular teeth, accessory unguis triangular, with serrated dorsal margin, main unguis smooth and curved (Fig. 3h). Distolateral angle of exopodal uropod angular, without fixed tooth, with small movable spine.

REMARKS. The examined specimens are similar to the original species description given by Fujino and Miyake [1969]. The species clearly differs from the congeners possessing small submarginal tubercle-like teeth along cutting edges of fixed finger of chela of both pereiopods II (Fig. 3).

HOSTS. The host sponge species of the specimen from French Polynesia remains unidentified. Specimens from Japan were found inside large yellow-whitish sponges of the genus Callyspongia Duchassaing, Michelotti, 1864 (Porifera: Demospongiae: Callyspongiidae) (possibly Callyspongia confoederata [sensu Ridley, 1884]) taken from nets of fisherman. The other pontoniine species found within the same sponge host is Isopericlimenaeus gorgonidarum (Balss, 1913) (Crustacea: Decapoda: Pontoniinae) [Marin, 2012: 371]. 

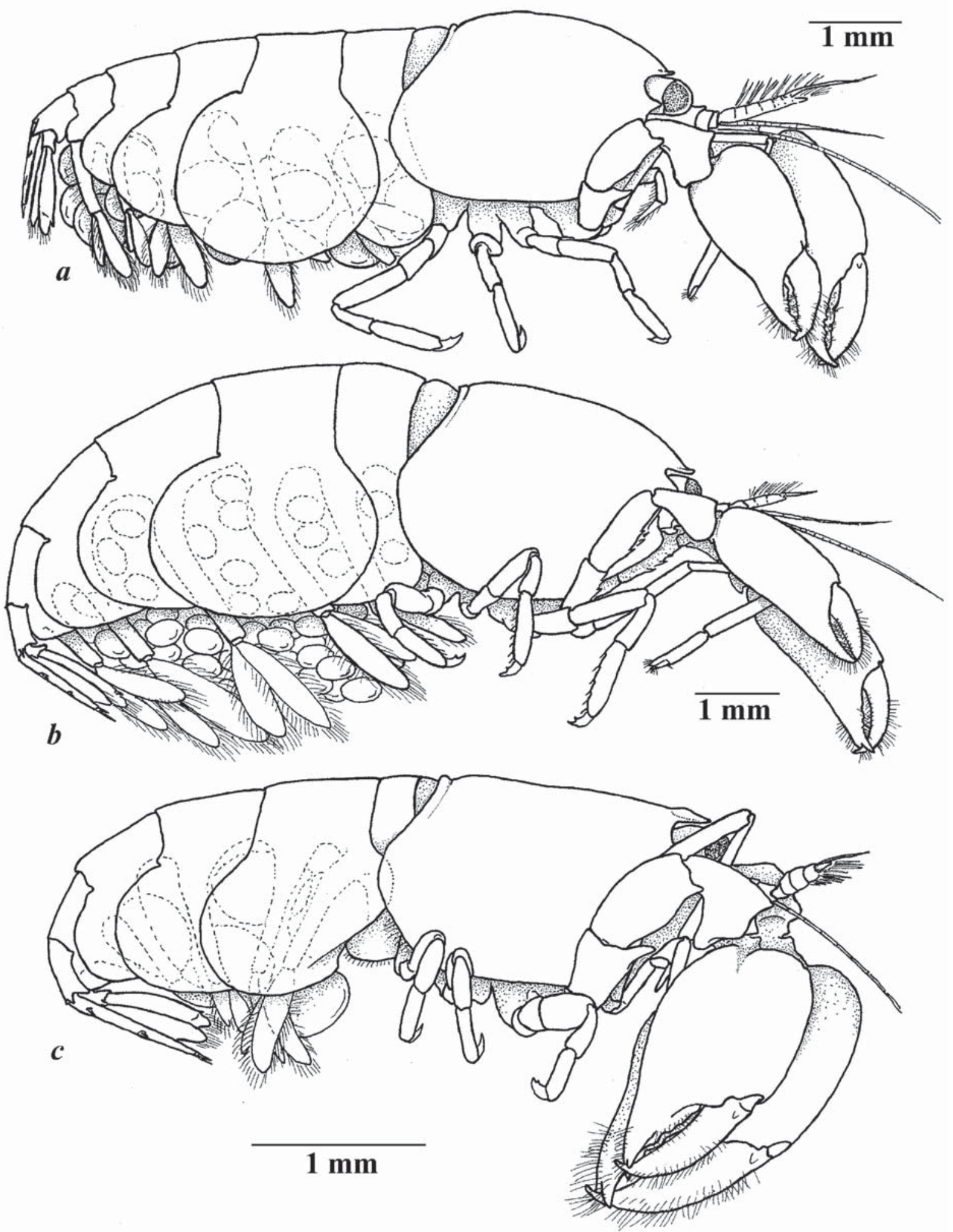

Fig. 1. Ovigerous females of Onycocaris callyspongiae Fujino, Miyake, 1969 (a), Onycocaris spinosa Fujino, Miyake, 1969 (b), and holotype female of Onycocaris zarenkovi sp.n. (c).

Рис. 1. Половозрелые самки Onycocaris callyspongiae Fujino, Miyake, 1969 (a), Onycocaris spinosa Fujino, Miyake, 1969 (b) и голотип (половозрелая самка) Onycocaris zarenkovi sp.n. (c) 


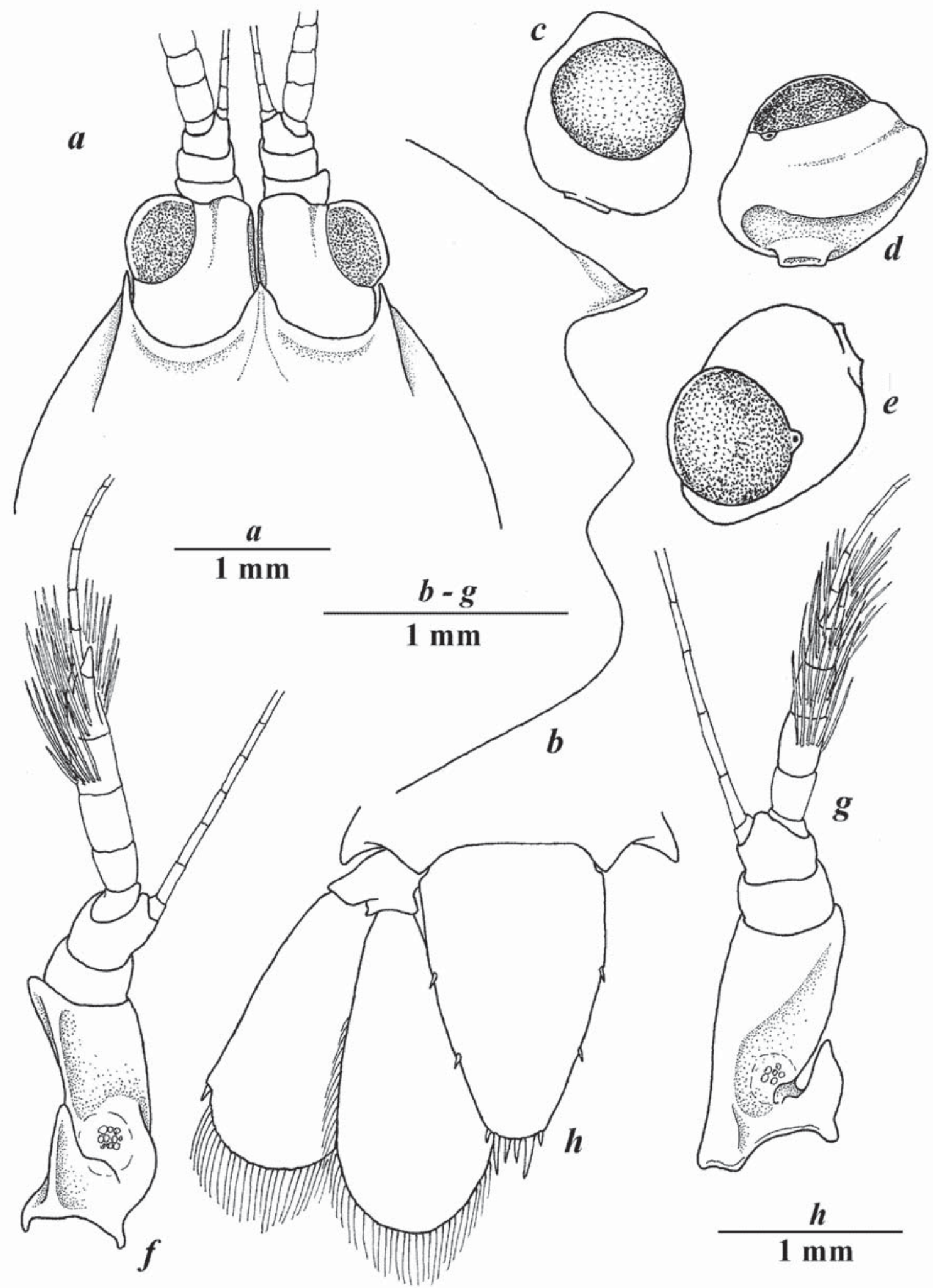

Fig. 2. Onycocaris callyspongiae Fujino, Miyake, 1969, ovigerous females (UF: Arthropoda: 2329) from Moorea: $a$ - front of carapace, dorsal view; $b$ - same, lateral view; $c-e$ - eyes; $f, g$ - antennules; $h$ - telson and uropods.

Рис. 2. Onycocaris callyspongiae Fujino, Miyake, 1969, половозрелая самка (UF: Arthropoda: 2329), Муреа: $a$ — передняя часть карапакса, вид сверху; $b$ - тоже, вид сбоку; $c-e$ - глаза; $f, g$ - антеннулы; $h$ - тельсон и уроподы. 


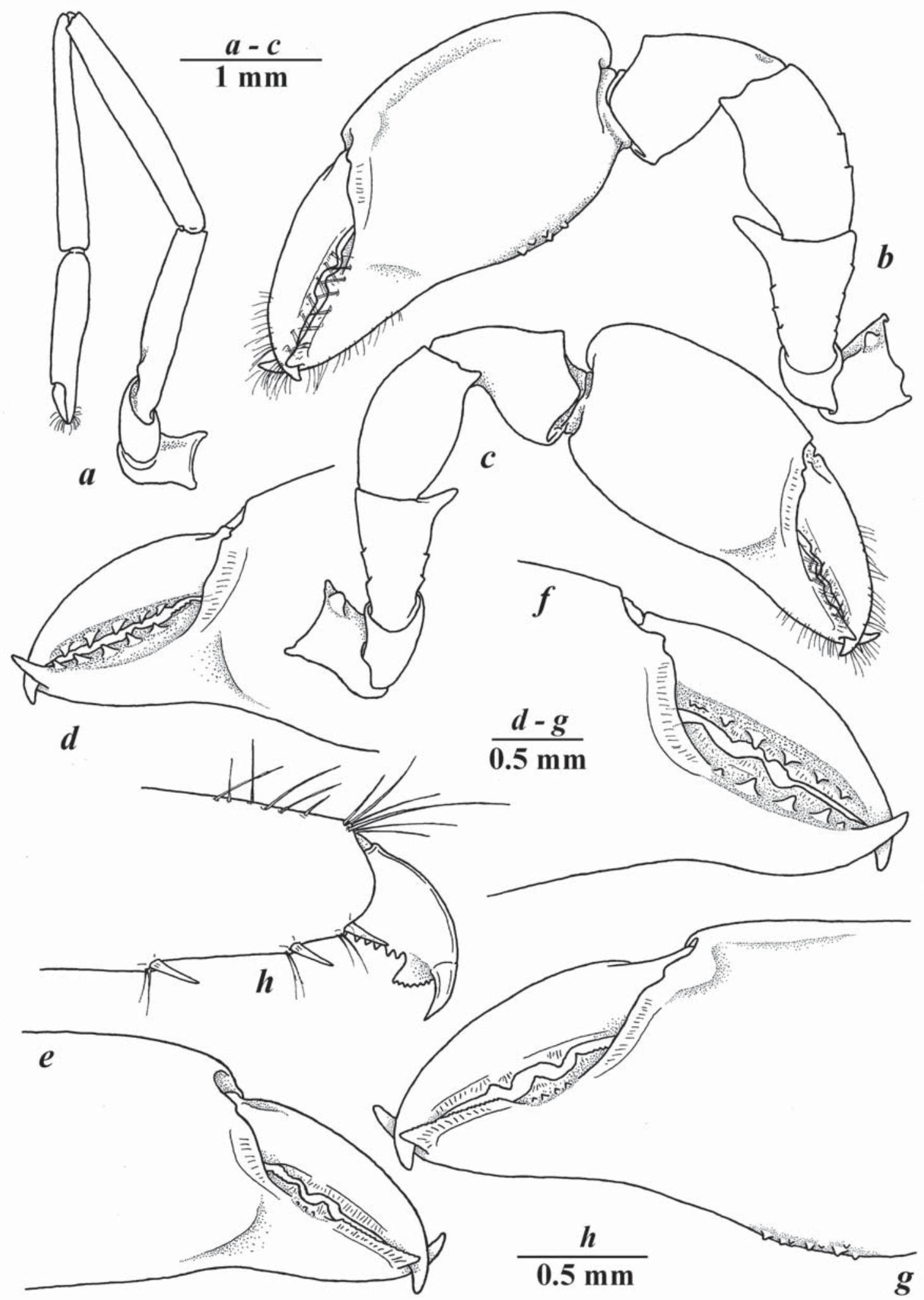

Fig. 3. Onycocaris callyspongiae Fujino, Miyake, 1969, ovigerous females (UF: Arthropoda: 2329) from Moorea: $a$ - pereiopod I; $b$, $c$ - pereiopods II; $d-g$ - fingers of pereiopods II ( $d, e$ - minor, $f, g$ - major); $h$ - pereiopod III.

Рис. 3. Onycocaris callyspongiae Fujino, Miyake, 1969, половозрелая самка (UF: Arthropoda: 2329), Муреа: $a$ - переопода I; $b$, $c$ - переоподы II; $d-g$ - пальцы переопод II ( $d, e-$ малой клешни, $f, g-$ большей клешни); $h$ - переопода III. 
According to the author's observations a pair of $O$. callyspongiae usually occupies a small niche within the body of host sponge; no movements of shrimps outside of the niche were recorded.

DISTRIBUTION. This is the first record of the species from Moorea, Society Islands, French Polynesia. The species is probably widely distributed; presently recorded from tropical western Indian Ocean (Tanzania and Maldives), and tropical coasts of Korea and Japan (the type locality) [Fujino, Miyake, 1969; Bruce, 1976; De Grave, 2001; Koo, Kim, 2003; Komai, Itou, 2012].

\section{Onycocaris spinosa Fujino et Miyake, 1969} Figs $1 b, 4,5$.

Onycocaris spinosa Fujino, Miyake, 1969: 429, figs. 13-15 [type locality: Ryukyu Islands, Japan].

MATERIAL EXAMINED. 1 ovigerous female (pcl. $3.1 \mathrm{~mm}$ ), UF: Arthropoda: 18269 (AUST-2299), Pacific Ocean, Australia, Queensland, N of Lizard Island, AUST-ST-108MT, $14.6504^{\circ}$ $145.4621^{\circ}$, sponge at the base of dead Pocillopora, rubble extraction, coll. Molly Timers, 20.02. 2009.

DIAGNOSIS. Small-sized species with subcylindrical body (Fig. 1b). Carapace (Figs 4a, b) smooth, swollen, with bluntly produced inferior orbital angle; antennal tooth absent. Rostrum (Fig. $4 b$ ) short, triangular, not reaching middle of the eyestalk, with deep unarmed dorsal lamina, with feebly developed ventral lamina and well developed lateral lamina, proximal lateral rostral lamina (Fig. 4a) feebly developed; orbit feebly developed; pterygostomial angle bluntly rounded. Abdominal somites smooth; pleurae of abdominal somites I-V rounded (Fig. 1b). Telson (Fig. 4g) stout, about twice longer than proximal width, narrowing distally, with 2 pairs of small dorsal marginal spines at 0.4 and 0.75 of telson length; distal margin of telson armed with 3 pairs of spines. Eyes (Fig. $4 a$ ) stout, with reduced suboval cornea and wide flattened stout eyestalk, without lateral depression. Antennule (Figs $4 c$, d) slightly reduced, compressed; with blunt stylocerite and small blunt tooth at distolateral angle, without submarginal ventral tooth (Fig. 4c). Antenna (Fig. 4e) normal, with unarmed basicerite, with relatively robust carpocerite reaching the distal margin of the blade of scaphocerite, with slightly reduced wide scaphocerite armed with distinct distolateral tooth (Fig. 4f). Mouthparts normal, characteristic for the genus. Pereiopod I (Fig. 4i) with slender segments; palm about 2.5 times longer than fingers; dactylus and fixed finger simple, with entire cutting margins, fixed finger with bifurcated tip, dactylus with simple tip (Figs $4 j-l$ ). Pereiopod II similar in shape and almost equal in size (Fig. $5 a, b$ ); ischium and merus armed with small sharp curved teeth along ventral angle (Fig. 5c); carpus triangular, not overlapping carpo-propodal articulation, with distodorsal angle slightly produced dorsally; propodus subcylindrical, slightly compressed, about twice longer than wide, with smooth parallel lateral margins; fingers (Figs $5 e-h)$ relatively stout, with cutting margin almost straight along the length, with 1-2 triangular teeth at the median part, with sharp and curved tips, with an additional sharp submarginal plate at the distal margin of fixed fingers. Pereiopod III stout, with smooth segments; propodus with straight lateral margins, with 2 single stout spines in at the distal part of ventral margin and a pair of stout sharp spines at distoventral angle; dactylus (Fig. 5i) stout, biunguiculate, ventral margin armed with 7 large triangular teeth along the length, accessory unguis triangular in shape, smooth, with small notch distolaterally, main unguis smooth and curved. Distolateral margin of exopodal uropod with blunt distolateral margin and small movable spine (Fig. 4h).

REMARKS. The specimen morphologically agrees with the original description of the species presented by Fujino and Miyake [1969]. Onycocaris spinosa clearly differs from the congeners by the presence of sharp curved teeth along ventral margin of ischium and merus of pereiopod II (Fig. 5c).

DISTRIBUTION. The species is presently known from Japan (the type locality) and the Great Barrier Reef of Australia [Fujino, Miyake, 1969; Bruce, 1990, 2010a, b; De Grave, 2001].

\section{Onycocaris zarenkovi sp.n.}

Figs 1c, 6-8.

MATERIAL EXAMINED. Holotype: 1 ovigerous female (pcl. $1.4 \mathrm{~mm}$ ), UF: Arthropoda: 2329 (BMOO-06002, MBIO25433), Pacific Ocean, French Polynesia, Society Islands, Moorea Gump Reef, silty lagoon with rocks and coral stands, associated with small cryptic sponge (preserved with specimen). Coll. Steve StonesHavas, Phil Bock, Sarah McPherson and Seabird McKeon, 16.10.2009.

DESCRIPTION. Holotype female. Small-sized shrimps with cylindrical body (Fig. 1c). Carapace swollen, smooth (Fig. 1c), with distally produced triangular inferior orbital angle (Figs $6 a, b$ ), antennal tooth absent. Rostrum (Fig. 6b) short, compressed, not reaching middle of the eyestalk, with tip slightly turned upward, with well developed unarmed dorsal lamina, with feebly developed unarmed ventral margin, with lateral lamina well developed, wide. Orbit well developed. Pterygostomial angle bluntly produced distally.

Abdominal somites smooth; pleurae of abdominal somites I-V rounded (Fig. 1c). Telson (Fig. 7d) about twice as long as proximal width, narrowing distally, with 2 pairs of small dorsal marginal spines at 0.4 and 0.8 of telson length; distal margin of the telson armed with 3 pairs of spines including a pair of short stout lateral spines, a pair of long slender intermediate spines and a pair of simple medial spines almost equal to intermediate spines.

Eyes (Figs $6 c-f$ ) large and stout, with reduced flattened eyestalk and suboval cornea, with deep wide depression distoventrally (Fig. 6a, $b, f, e$ ).

Antennula (Figs $6 g, h$ ) feebly developed, with reduced segments; basal segment about twice as long as wide, with deep depression in proximal part of basal antennular segment (Fig. 6h), with well-developed blunt stylocerite, without submarginal ventral tooth, with distolateral angle unarmed; distal segments stout, equal, 


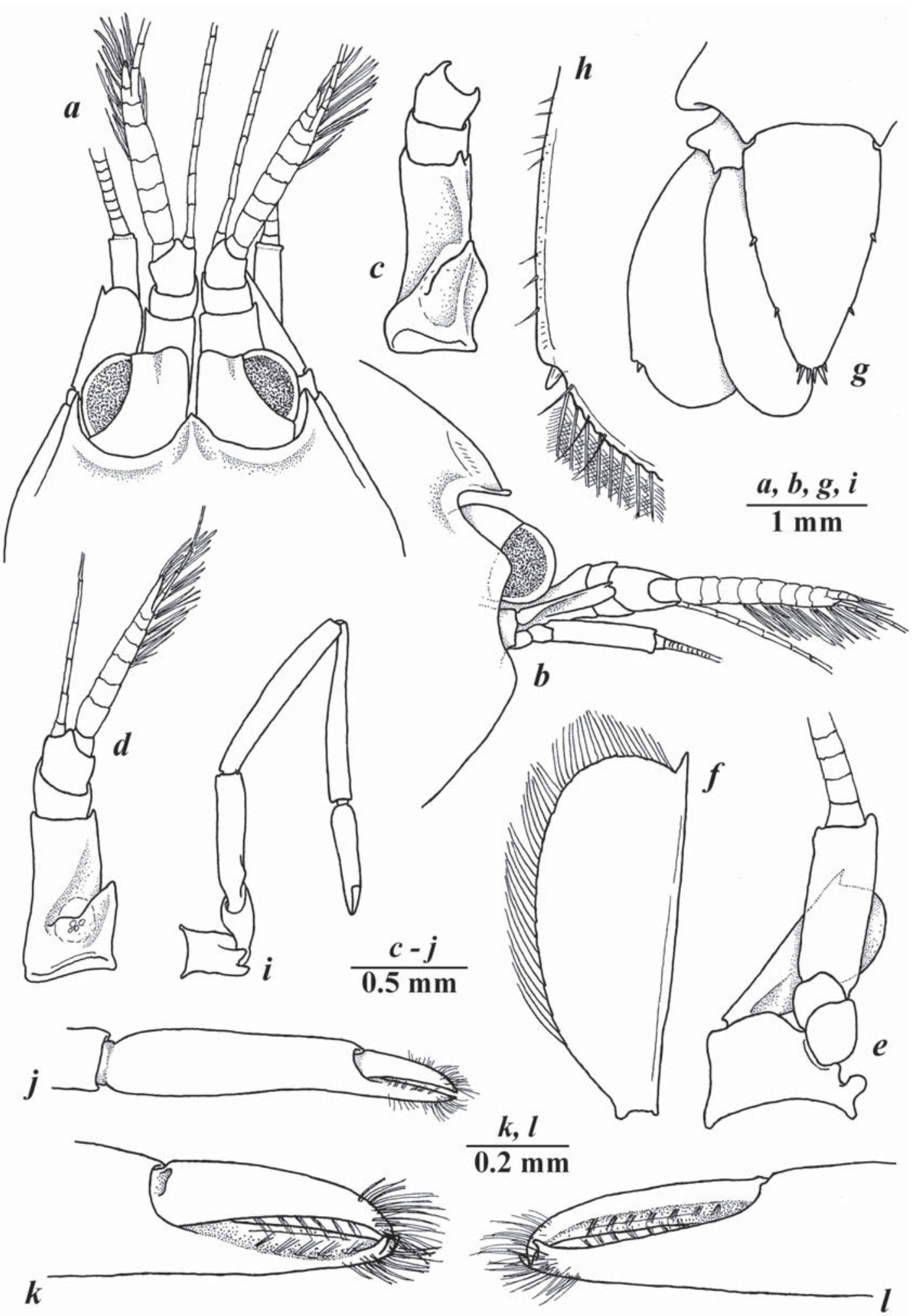

Fig. 4. Onycocaris spinosa Fujino, Miyake, 1969, ovigerous female (UF: Arthropoda: 18269), Queensland, Australia: $a, b-$ front of carapace; $c$ - antennular peduncle; $d-$ antennule; $e$ - antenna; $f$ - scaphocerite; $g-$ telson and uropods; $h-$ lateral margin of uropodal exopod; $i$ - pereiopod I; $j$ - chela of pereiopod I; $k, l$ - same, fingers of chela.

Рис. 4. Onycocaris spinosa Fujino, Miyake, 1969, половозрелая самка (UF: Arthropoda: 18269), Квинслэнд, Австралия: $a, b-$ передняя часть карапакса; $c$ - стебелек антеннулы; $d$ - антеннула; $e$ - антенна; $f$ - скафоцерит; $\mathrm{g}$ - тельсон и уроподы; $\mathrm{h}-$ боковой край экзопода уропод; $i$ - переопода $\mathrm{I} ; j-$ клешня переопод $\mathrm{I} ; k, l$ - то же, пальцы клешни. 


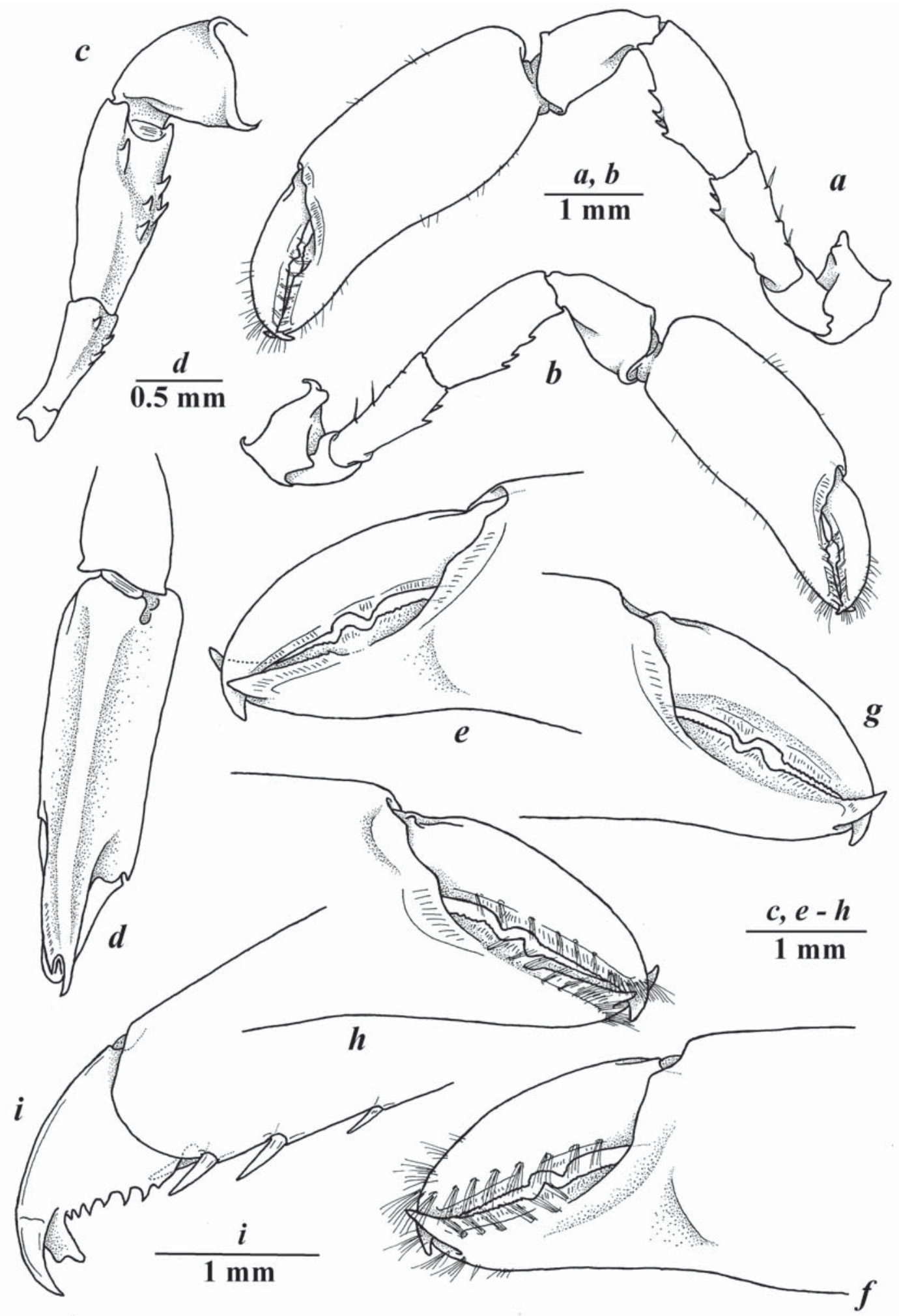

Fig. 5. Onycocaris spinosa Fujino, Miyake, 1969, ovigerous female (UF: Arthropoda: 18269), Queensland, Australia: $a, b-$ pereiopods II; $c$ - proximal segment of pereiopod II; $d$ - distal segments of major pereiopod II, ventral view; $e-h$ - fingers of pereiopod II; $i$ - pereiopod III.

Pис. 5. Onycocaris spinosa Fujino, Miyake, 1969, половозрелая самка (UF: Arthropoda: 18269), Квинслэнд, Австралия: $a, b-$ переоподы II; $c$ - проксимальные сегменты переоподы II (клешни); $d$ - дистальные сегменты большей переоподы II (клешни), вид снизу; $e-h$ - пальцы переопод II; $i$ - переопода III. 


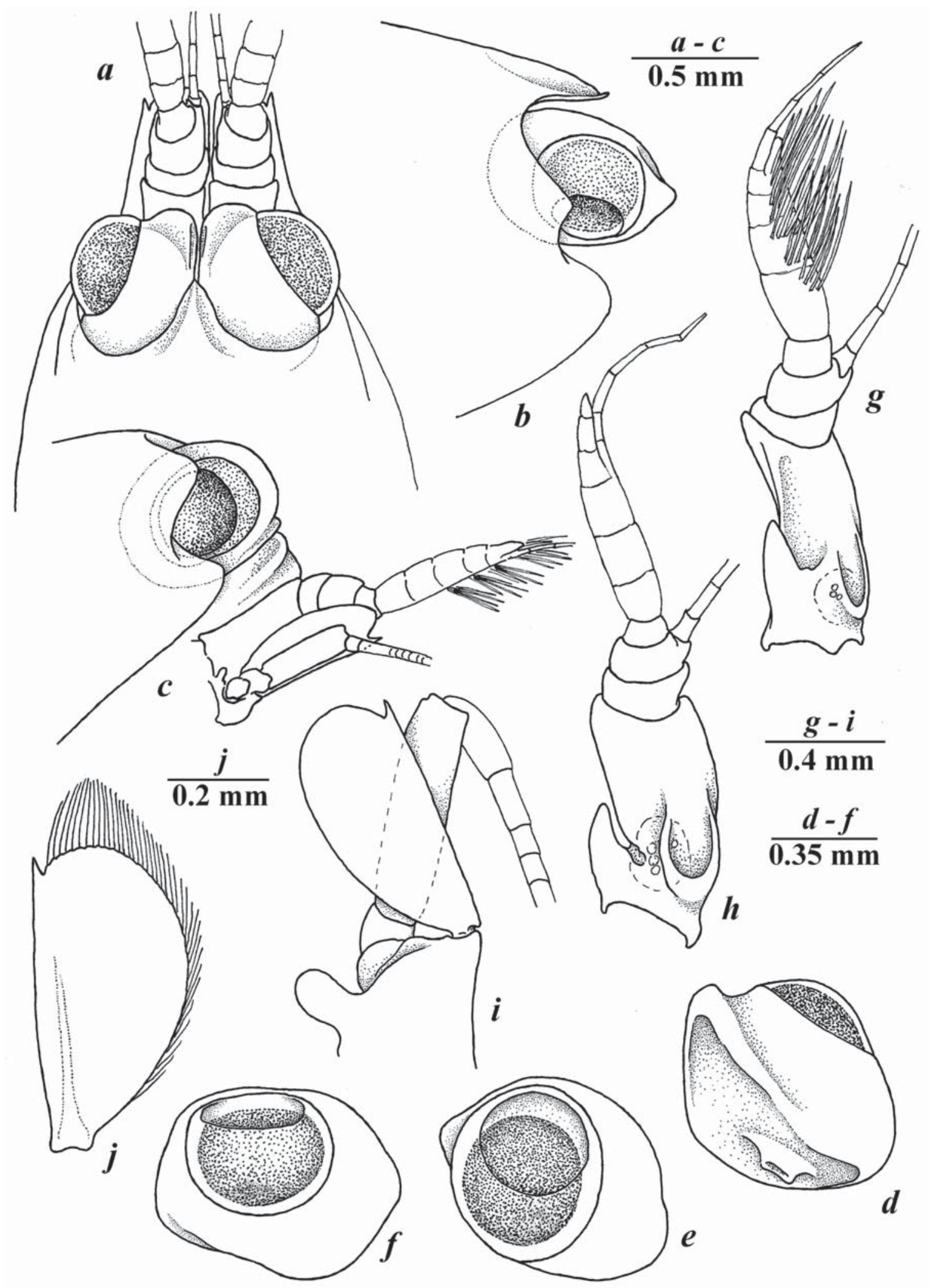

Fig. 6. Onycocaris zarenkovi sp.n., holotype female (UF: Arthropoda: 2329), Moorea: $a, b-$ front of carapace; $c-$ distolateral margin of carapace, ventral view; $d-f$ - eyes; $g, h-$ antennule; $i$ - antenna; $j-$ scaphocerite.

Pис. 6. Onycocaris zarenkovi sp.n., голотип, половозрелая самка (UF: Arthropoda: 2329), Mypea: $a$, $b$ - передняя часть карапакса; $c$ - дистолатеральный край карапакса, вид снизу; $d-f$ - глаз; $g, h$ - антеннула; $i$ - антенна; $j$ - скафоцерит. 


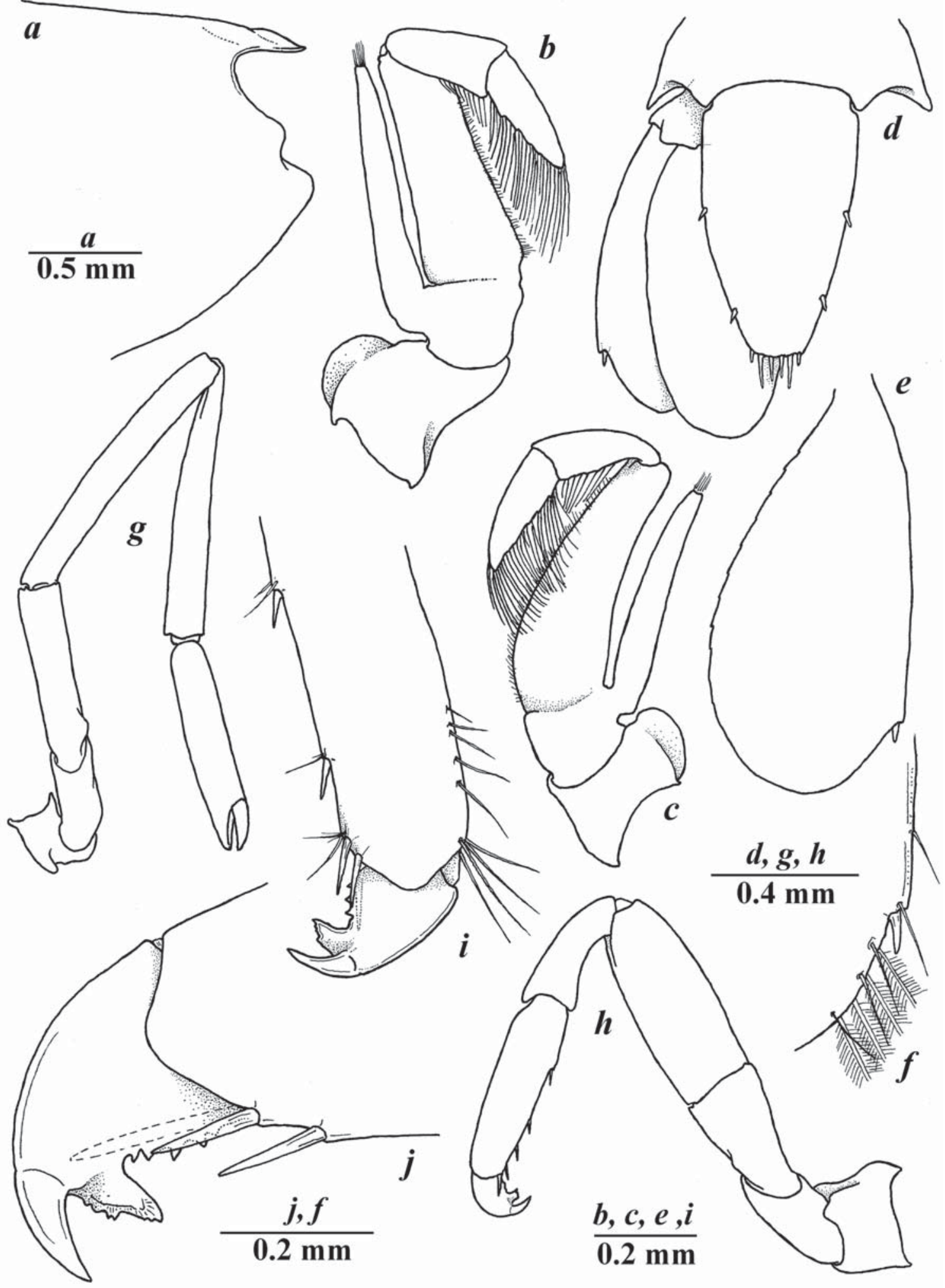

Fig. 7. Onycocaris zarenkovi sp.n., holotype female (UF: Arthropoda: 2329), Moorea: $a$ - front of carapace; $b, c$ - maxilliped III; $d$ - telson and uropods; $e$ - uropodal exopod; $f$ - same, distolateral margin; $g$ - pereiopod I; $h$ - pereiopod III; $i, j$ - distal propodus and dactylus of pereiopod III.

Рис. 7. Onycocaris zarenkovi sp.n., голотип, половозрелая самка (UF: Arthropoda: 2329), Mypea: a - передняя часть карапакса; $b, c$ - максиллипеда III; $d$ - тельсон и уроподы; $e-$ экзопод уропод; $f$ - дистолатеральный край экзопода уропод; $g$ переопода I; $h$ - переопода III; $i, j$ - дистальная часть проподуса и дактилус переопод III. 


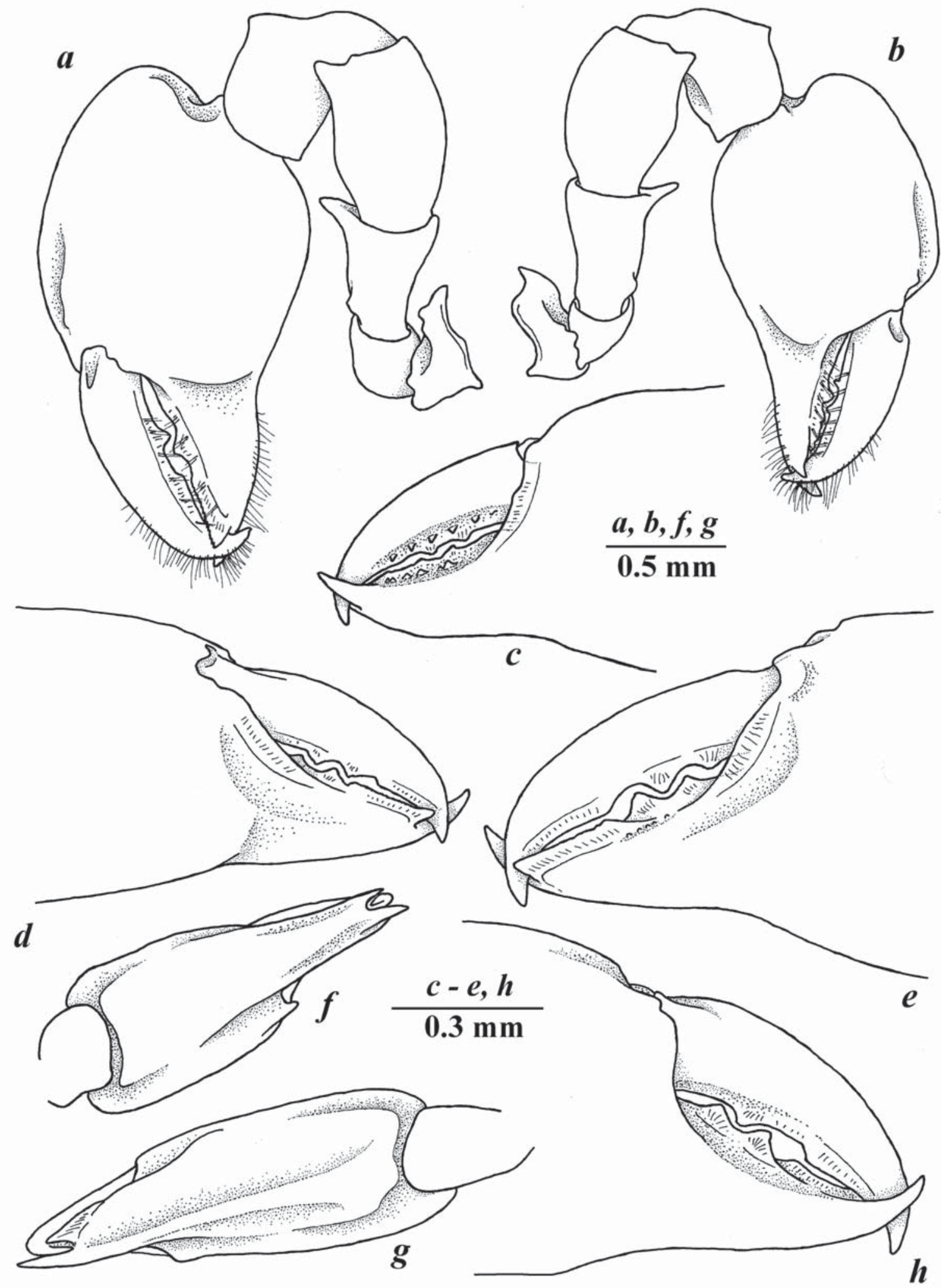

Fig. 8. Onycocaris zarenkovi sp.n., holotype female (UF: Arthropoda: 2329), Moorea: $a, b$ - pereiopods II; $c, d$ - fingers of minor pereiopod II; e, $h$ - fingers of major pereiopod II; $f, g$ - distal segments of pereiopod II, ventral view.

Рис. 8. Onycocaris zarenkovi sp.n., голотип, половозрелая самка (UF: Arthropoda: 2329), Муреa: $a, b-$ переоподы II; $c, d-$ пальцы меньшей переоподы II (клешни); $e, h$ — пальцы большей переоподы II (клешни); $f, g$ - дистальные сегменты переопод II, вид снизу. 
about twice wider than long; distal proximal part of upper antennular flagellum swollen, with 3 separate segments, shorter ramus with 3 segments.

Antenna (Fig. 6i) well developed, with unarmed basicerite; carpocerite long and slender, about 3.5 times longer than wide, overreaching the blade of scaphocerite; scaphocerite (Fig. 6j) wide, about twice longer than maximal width, slightly overreaching distal antennular segment, with well developed, acute distolateral tooth not reaching to the distal margin of the blade.

Pereiopod I (Fig. 7g) normal, with slender unarmed segments; coxal segment with curved lobe distoventrally; basis about 1.5 times as long as wide; ischium about 3 times as long as wide; merus slender, about 6 times as long as wide; carpus slender, longer than merus, about 6 times as long as wide, slightly widening distally, with several stout simple setae at carpo-propodal articulation; palm cylindrical, about 5 times as long as wide; dactylus and fixed finger stout, about 2.5 times as long as wide, simple, curved, tapering distally, with entire cutting edges and simple tips.

Pereiopods II similar in shape and slightly unequal in size, with robust unarmed segments (Fig. 8a, b); basis about as long as wide; ischium about 1.5 times as long as maximal width, with straight lateral margins and well developed blunt distolateral tooth; merus swollen in medial part, about 1.2 times as long as wide, with bluntly produced disto-ventral angle; carpus flaring distally, swollen in medial part, about as long as wide, not overlapping carpo-propodal articulation, with disto-dorsal margin bluntly produced dorsally, with distal margin rounded; palm (Figs $8 f, g$ ) stout, compressed, swollen in medial part, with smooth margins, about as long as wide; fiõed fingers (Figs $8 c, d, e, h$ ) stout, equal to the length of palm, about twice longer than wide, cutting edges with 2 triangular proximal teeth and straight in its distal part, with several tubercle-like submarginal teeth along inner side in medial part of cutting margin, with additional straight sharp cutting plate at inner side of cutting edge; dactylus equal to fixed fingers, cutting edges with 2 triangular proximal teeth and straight in its distal part, dactylus of major pereiopod II without additional submarginal teeth; dactylus of minor pereiopod II with 5 tubercles like submarginal teeth along inner margin of cutting edge (Fig. 8c).

Pereiopod III (Fig. 7h) normal, with unarmed robust segments; ischium about 1.5 times longer than wide; merus about 2.5 times longer than wide, with straight lateral margins; carpus flaring distally, about 2.5 times as long as maximal width; propodus stout, about 3 times as long as wide, with straight and smooth lateral margins, with 4 single simple sharp spines along ventral margin and a pair of slender straight spines at the disto-ventral angle; dactylus (Fig. 7i) strong and stout, biunguiculate, ventral margin armed with 5 small triangular teeth along the length; accessory unguis strong, with serrated dorsal and smooth ventral margins; main unguis curved and smooth (Fig. 7j). Pereiopods III-V similar.
Pleopods normal, without specific features. Uropods wide, exceeding telson; distolateral margin of exopod angular, without fixed tooth, with small movable spine (Fig. 7e).

DIFFERENTIAL DIAGNOSIS. This new species is referring to the largest group within the genus including O. amakusensis, O. aualitica, O. bocki, $O$. callyspongiae, O. oligodentata, O. quadratophthalma, $O$. stradbrockei and $O$. trullata generally characterized by a short toothless rostrum and stout pereiopods II almost similar in size and shape [see key to the species presented by Bruce, 2011]. The new species is morphologically most similar to O. callyspongiae by such characters as a short and slightly turned upward rostrum, the specific flattened shape of eyes, the morphology of antennula without distolateral tooth, similar compressed chelipeds (pereiopod II) with a row of small tubercle-like teeth on the inner side cutting edge of fixed fingers and the form of dactylus of pereiopod III. Nevertheless, the new species can be clearly separated from $O$. callyspongiae by significantly smaller body size, the presence of well marked deep depression on eyes, much reduced antennula with the basal segment showing deep depression in proxi-ventral part and shorter distal segments, more stout pereiopods II with smooth lateral margins of all segments and quadrate compressed chela as well as smaller size and lesser number of tubercle-like submarginal teeth on the inner side of the cutting edges of fixed fingers; the dactylus of ambulatory pereiopods in $O$. zarenkovi sp.n. shows significantly slender accessory unguis. Morphology of the frontal part of carapace, eyes and antennula in $O$. $z a$ renkovi sp.n. are highly adapted to the small body size. From morphologically similar $O$. amakusensis the new species clearly differs by the absence of distally produced angle of carpus of pereiopods II (see Fig. 14d, e).

COLORATION. Unknown.

ETYMOLOGY. The species is named after the famous Russian carcinologist, Nikolay A. Zarenkov (Moscow).

HOSTS. Unidentified cryptic calcareous sponge.

DISTRIBUTION. The species is presently known only from the type locality - Moorea, French Polynesia.

\section{Onycocaris rudolfi sp.n.} Figs 9-13.

MATERIAL EXAMINED. Holotype: 1 male (pcl. $2.2 \mathrm{~mm}$ ), UF: Arthropoda: 16257 (BMOO-5103, MIB-191, MBIO20877).

Paratype: 1 ovigerous female paratype (pcl. $3.0 \mathrm{~mm}$ ) (UF: Arthropoda: 16256, BMOO-5102, MBIO20876), Pacific Ocean, French Polynesia, Society Islands, Moorea, $17.4767^{\circ} 149.83^{\circ}$, between Cook's Bay and Sheraton, rocks, 4-7 m, coll. JI, S. McKeon (processed by A. Anker), 4.11.2008 (16257, 16256 DNA subsample).

DESCRIPTION. Holotype male and allotype ovigerous female. Medium-sized shrimps with cylindrical body (Fig. 9). Carapace swollen, smooth, with distally triangularly produced blunt inferior orbital angle (Figs. 10a, 


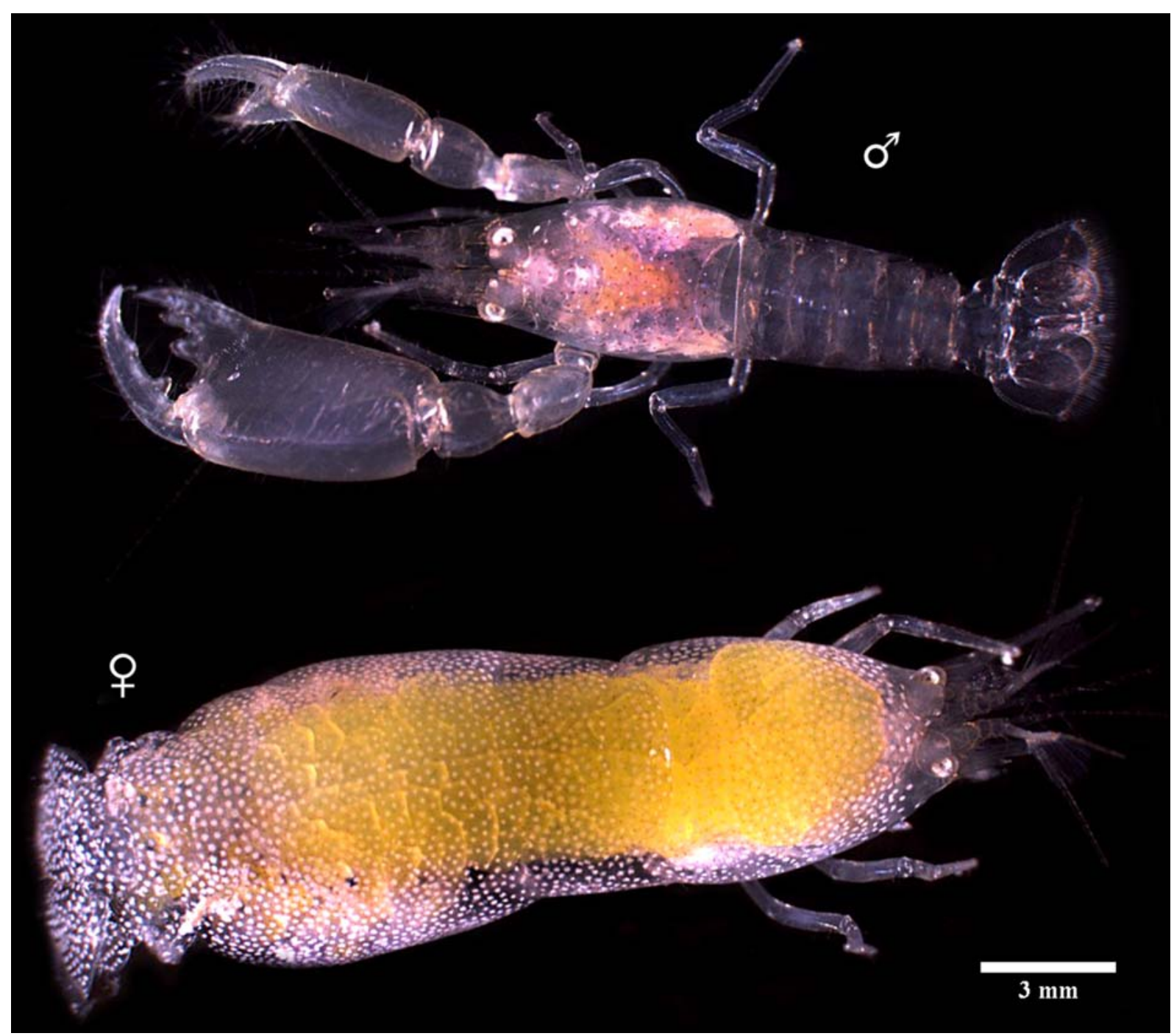

Fig. 9. Onycocaris rudolfi sp.n., holotype male (UF: Arthropoda: 16256) and ovigerous female (UF: Arthropoda: 16257), Moorea. General view and colour in life.

Рис. 9. Onycocaris rudolfi sp.n., голотип, самец (UF: Arthropoda: 16256) и половозрелая самка (UF: Arthropoda: 16257), Mypea. Общий вид и прижизненная окраска.

$b ; 11 a, b)$, antennal tooth absent. Rostrum relatively long, compressed, overreaching eyes, bearing developed dorsal carina with 3 small dorsal teeth; ventral margin feebly developed, unarmed; lateral lamina well developed, wide, forming well marked orbits. Pterygostomial angle bluntly produced distally (Figs 10b, $11 b)$.

Abdominal somites smooth; pleurae of abdominal somites I-V rounded. Telson (Fig. 10h) about twice as long as proximal width, narrowing distally, with 2 pairs of small dorsal marginal spines at 0.35 and 0.6 of telson length; distal margin of the telson armed with 3 pairs of spines including a pair of short stout lateral spines, a pair of long slender intermediate spines and a pair of simple medial spines twice shorter than intermediate spines.
Eyes (Figs 10c, d), well developed, large, with subcylindrical eyestalk and suboval cornea, without depression distoventrally.

Antennula (Fig. 10e, f) well developed, normal; basal segment about twice as long as wide, with well developed blunt triangular stylocerite, with large and sharp distolateral tooth reaching to the distal margin of the antepenultimate segment (Fig. 10e, $f$ ), without submarginal ventral tooth; distal segments equal, stout, about as long as wide; distal proximal part of upper antennular flagellum swollen, with 5 separate segments, shorter ramus with 3-4 segments.

Antenna (Fig. 10g) well developed; basicerite without distoventral tooth; carpocerite long and slender, about 5 times longer than wide, overreaching the blade of scaphocerite; scaphocerite wide, about 1.5 times 


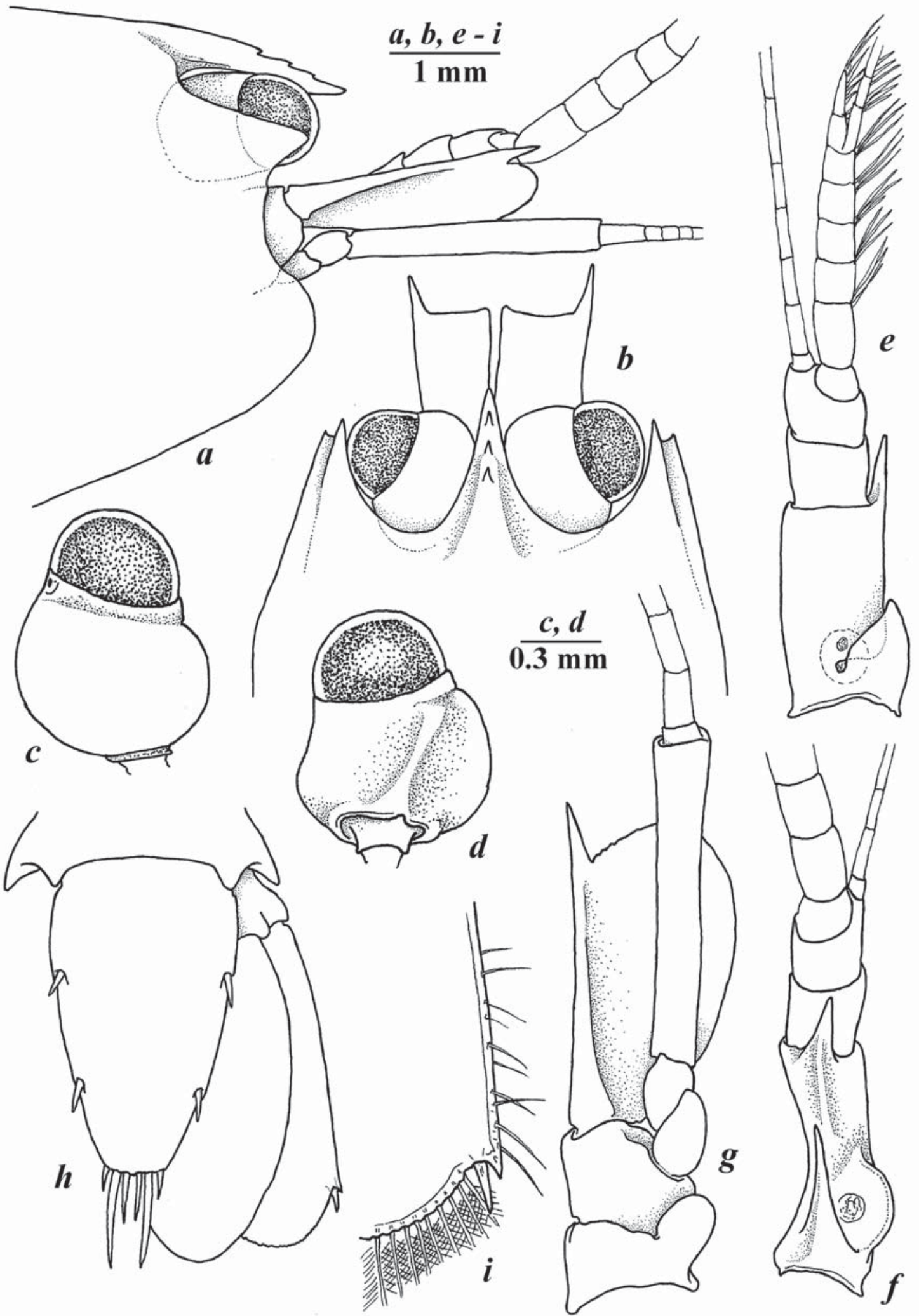

Fig. 10. Onycocaris rudolfi sp.n., holotype male (UF: Arthropoda: 16256), Moorea: $a, b-$ front of carapace; $c, d-$ eyes; $e, f-$ antennule; $g$ - antenna; $h$ - telson and uropods; $i$ - distolateral margin of uropodal exopod.

Рис. 10. Onycocaris rudolfi sp.n., голотип, самец (UF: Arthropoda: 16256), Мypea: $a, b$ - передняя часть карапакса; $c, d$ - глаз; $e, f$ - антеннула; $g$ - антенна; $h$ - тельсон и уроподы; $i$ - дистолатеральный край экзопода уропод. 


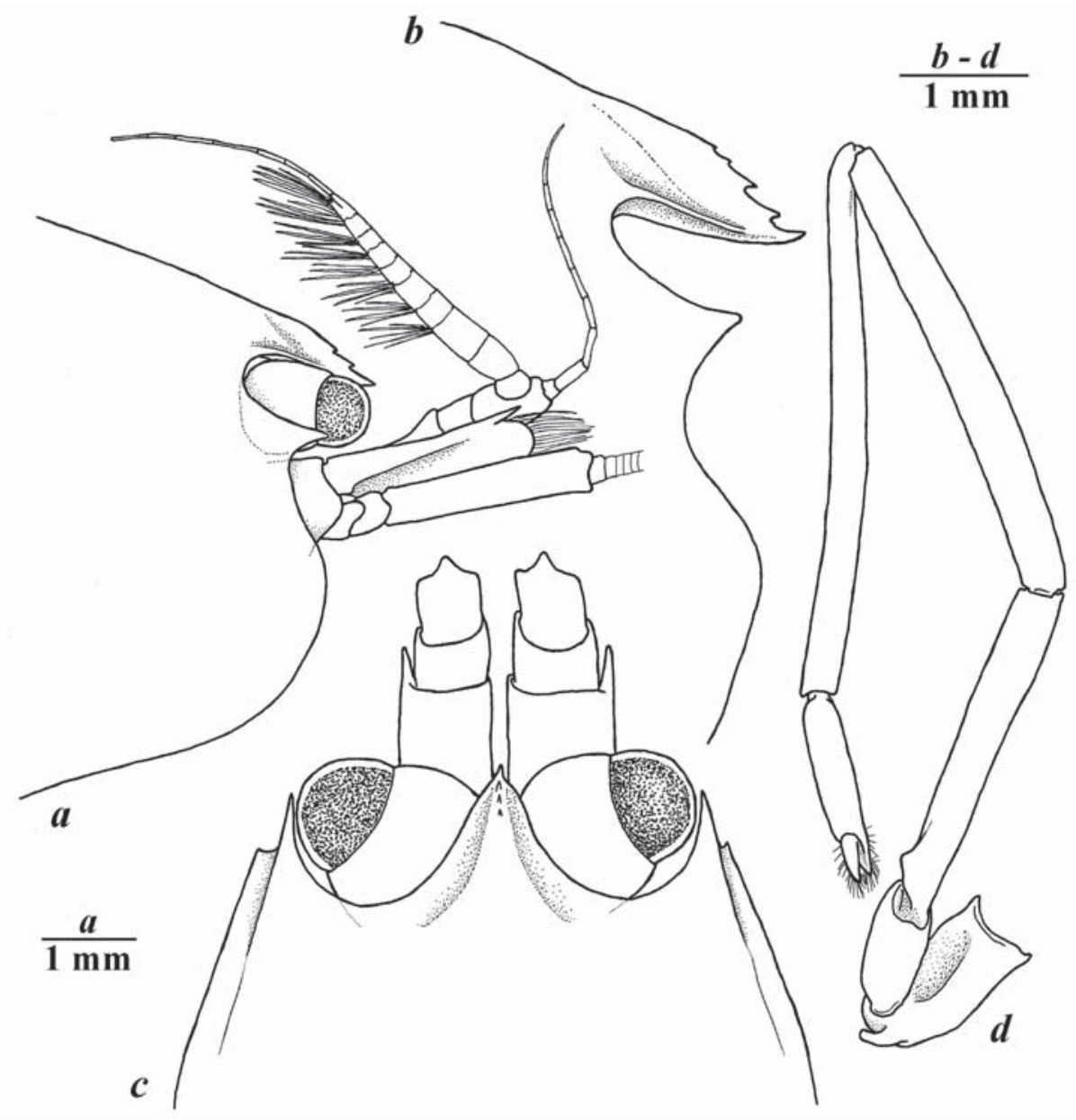

Fig. 11. Onycocaris rudolfi sp.n., ovigerous female (UF: Arthropoda: 16257), Moorea: $a-c-$ front of carapace; $d-$ pereiopod I. Рис. 11. Onycocaris rudolfi sp.n., половозрелая самка (UF: Arthropoda: 16257), Муреа: $a-c$ - передняя часть карапакса; $d$ переропода I.

longer than maximal width, slightly overreaching the distal margin of the antennular peduncle, with well developed acute distolateral tooth, overreaching the distal margin of the blade.

Pereiopod I (Figs 11d, 13a) normal, with slender unarmed segments; coxal segment as long as wide, with well marked curved lobe distoventrally; basis about as long as wide; ischium about 6 times as long as wide; merus slender, about 8 times as long as wide; carpus slender, longer than merus, about 10 times as long as distal width, widening distally, with several stout simple setae at carpo-propodal articulation; palm cylindrical, about 2.5 times shorter than carpus, about 4 times as long as wide; dactylus and fixed finger (Fig. 13b) stout, about twice longer than wide, subspatulated, curved, tapering distally, with entire cutting edges and simple tips.

Pereiopods II large, dissimilar in shape and size (Figs 12a,d). Major cheliped (Fig. 12a) with ischium about 1.5 times as long as maximal width, swollen, with convex lateral margins, disto-ventral angle not produced; merus swollen in medial part, disto-ventral margin without projection; carpus flaring distally, swollen in medial part, not overlapping carpo-propodal articulation, with disto-dorsal margin bluntly produced dorsally, with distal margin rounded; palm (Fig. 12ac) stout, subcylindrical, smooth, about 1.5 times as long as wide, with straight lateral margins; fixed finger stout, about half of the length of the palm, about 1.5 times as long as wide, proximally wide, triangular, slightly curved laterally, with cutting margin bearing 2 large teeth at its proximal and medial parts, with tip stout, simple; dactylus equal to fixed finger by the length, slender, about 3.5 times longer than wide, curved, smooth, with cutting margin bearing one large triangular tooth medially and straight distal part, with tip simple, curved. Minor cheliped (Fig. 12d) smaller than major, with ischium about 1.5 times as long as maximal width, swollen, with convex lateral margins, disto-ventral angle not produced; merus swollen in medial part, disto-ventral margin without projection; carpus flaring distally, swollen in medial part, not overlapping carpo-propodal articulation, with disto-dorsal margin produced, triangular, with distal margin round- 


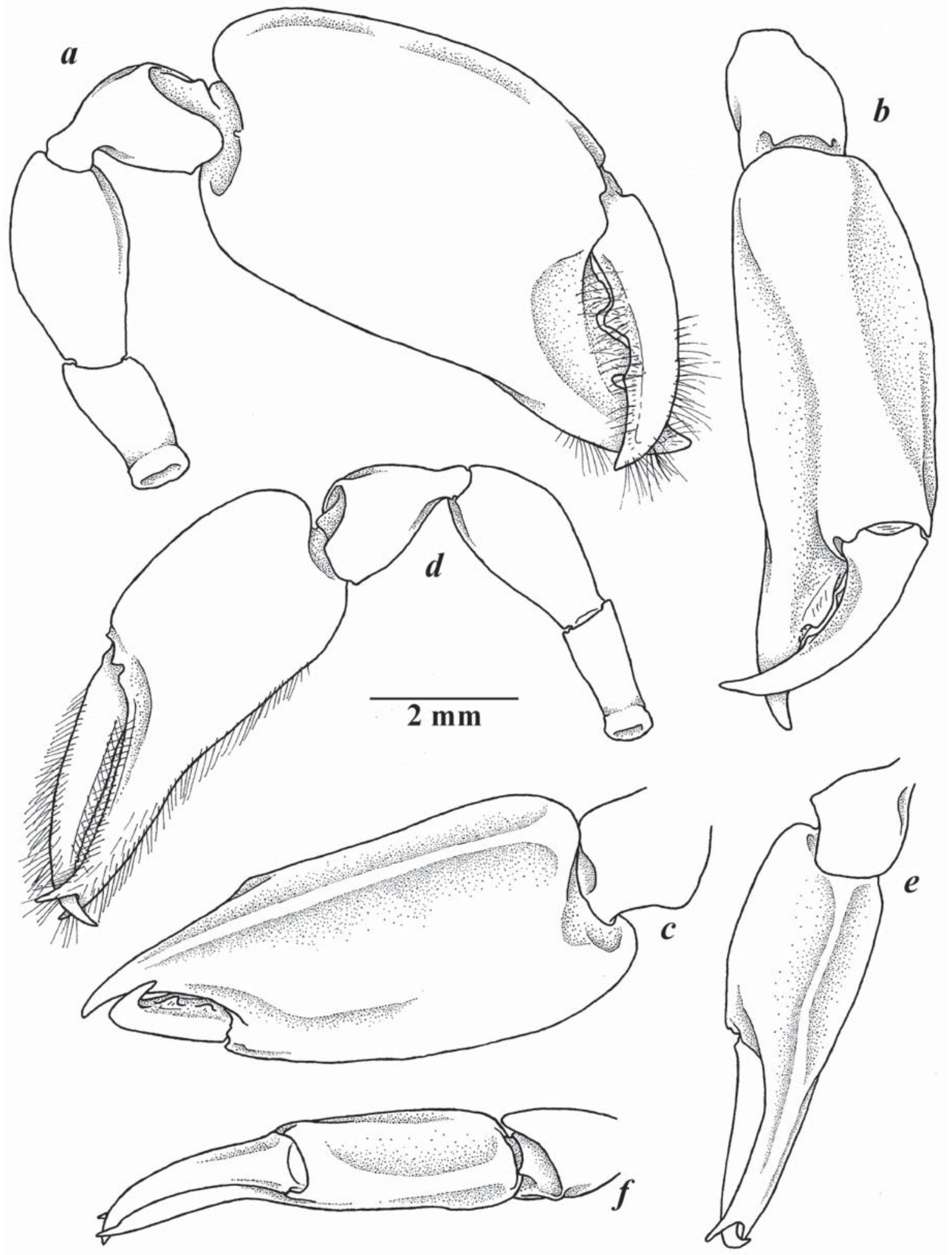

Fig. 12. Onycocaris rudolfi sp.n., holotype male (UF: Arthropoda: 16256), Moorea: $a$ - major pereiopod II; $b$ - chela of major pereiopod II, dorsal view; $c$ - same, ventral view; $d$ - minor pereiopod II; $e$ - chela of minor pereiopod II, dorsal view; $f$ - same, ventral view.

Рис. 12. Onycocaris rudolfi sp.n., голотип, самец (UF: Arthropoda: 16256), Муреа: $a$ - большая переопода II; $b$ - клешня большей переоподы II, вид сверху; $c$ - тоже, вид снизу; $d$ - малая переопода II; $e$ - клешня малой переоподы II, вид сверху; $f$ тоже, вид снизу. 

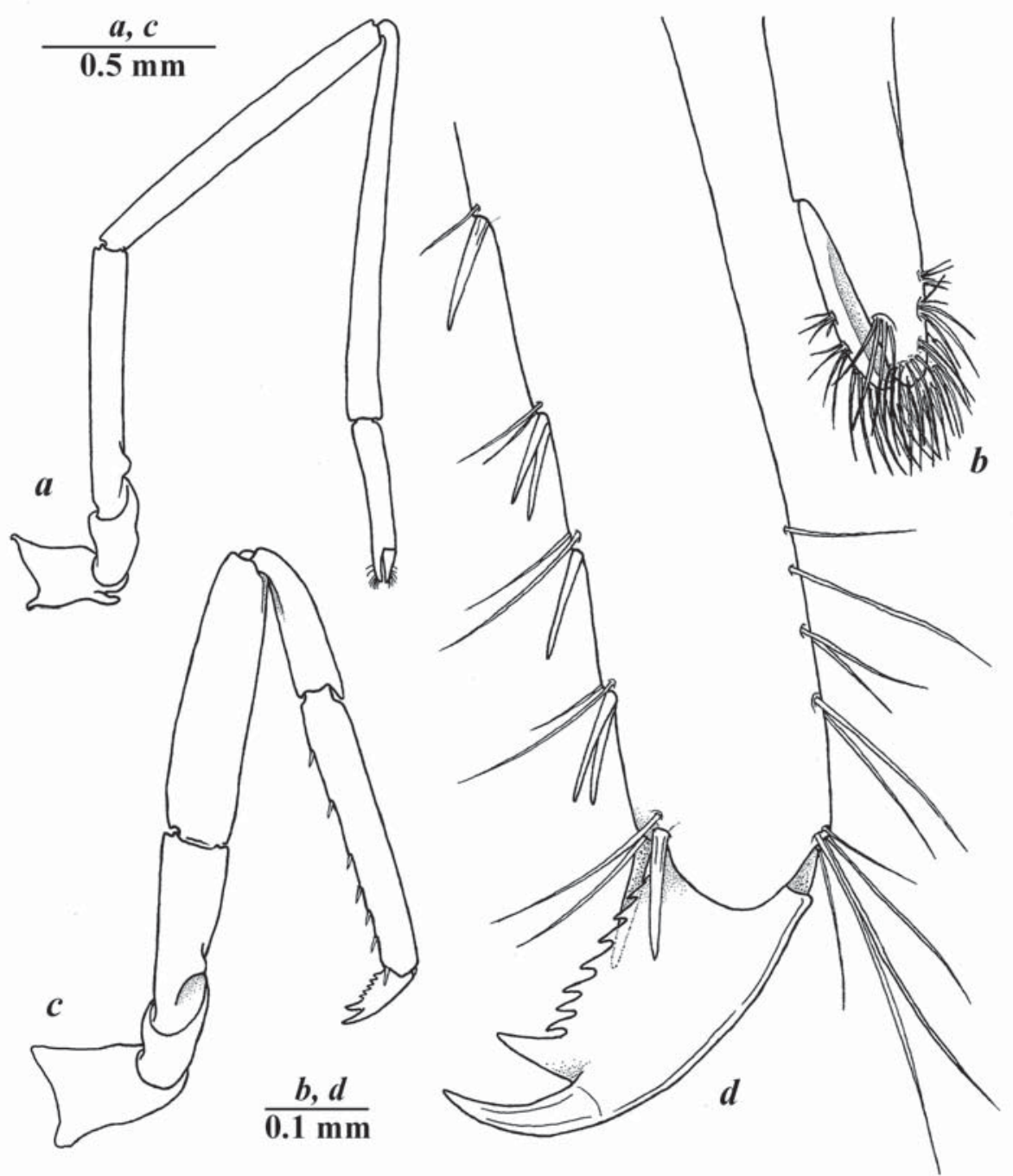

Fig. 13. Onycocaris rudolfi sp.n., holotype male (UF: Arthropoda: 16256), Moorea: $a$ - pereiopod I; $b-$ fingers of chela of pereiopod I; $c$ - pereiopod III; $d$ - distal propodus and dactylus of pereiopod III.

Рис. 13. Onycocaris rudolfi sp.n., голотип, самец (UF: Arthropoda: 16256), Mypea: $a$ - переопода I; $b$ - пальцы клешни переоподы I; $c$ - переоподаd III; $d$ - дистальная часть проподуса и дактилус переоподы III.

ed; palm (Fig. 12e,f) stout, compressed, smooth, about 1.5 times as long as wide, with straight lateral margins; fixed finger equal to the length of the palm, slender, about 3 times as long as proximal width, slightly curved laterally, with cutting margin straight, serrated, with tip bifurcated, sharp and curved; dactylus equal to fixed finger by the length, slender, about 3 times as long as proximal width, slightly curved laterally, with cutting margin straight, serrated, with tip simple, sharp and curved.

Pereiopod III (Fig. 13c) normal, with unarmed robust segments; ischium about 2.5 times longer than wide; merus about 2.5 times longer than wide, with straight lateral margins; carpus relatively slender, flaring distally, about 2.5 times as long as maximal width; propodus stout, about 5.5 times as long as wide, with straight and smooth lateral margins, with 6 single sim- ple spines along ventral margin and a pair of slender straight spines at disto-ventral angle; dactylus (Fig. $13 d$ ) strong and stout, biunguiculate, with 7-8 triangular teeth along its ventral margin; accessory unguis strong, triangular, with smooth margins; main unguis curved, smooth, and sharp. Pereiopods III-V similar.

Pleopods normal, without specific features. Uropods (Fig. 10h) wide, exceeding telson; distolateral margin of exopod without fixed tooth, with small movable spine (Fig. 10i).

Paratype female generally similar to the holotype male; pereiopods II (chelipeds) missing. Carapace of female greatly swollen; rostrum overreaching eyes (Figs $11 a, c)$, with well-developed dorsal carina bearing 4 small teeth, orbital angle sharply produced, pterygostomial angle bluntly rounded. Pereiopod I with slender segments, with proportions similar to male (Fig. 11d). 
DIFFERENTIAL DIAGNOSIS. The species morphologically close to $O$. profunda Bruce, 1985 and $O$. temiri Marin, 2005 by the following features such as well-developed cylindrical eyes, slender pereiopod I, dissimilar shape and specific form of pereiopods II and characteristic form of the dactylus of pereiopod III $(O$. profunda Bruce, 1985 is known by damaged holotype female lacking pereiopods II [Bruce, 1985] but by other features clearly referring to this group).

The new species can be clearly separated from $O$. temiri by shorter rostrum with less developed dorsal rostral carina bearing very small dorsal teeth, stouter telson with rounded distal margin, and smooth dorsal margin of accessory unguis of dactyli of ambulatory pereiopods [see Marin, 2005]. The new species can be separated from $O$. profunda by more developed rostrum overreaching cornea, the presence of acute distolateral tooth on the proximal antennular segment, subspatulate fingers of pereiopod I, different form of accessory unguis of the dactyli of ambulatory pereiopods, and straight lateral margin of uropodal exopod [see Bruce, 1985]. By the form of the telson, the new species is morphologically similar to $O$. profunda see the key to the "Onycocaris profunda" species group below).

COLORATION. Generally body and appendages translucent; carapace, abdomen and telson with small white chromatophores (Fig. 9).

ETYMOLOGY. The species is named after the famous Russian carcinologist, Dr. Rudolf N. Burukovsky (Kaliningrad).

HOSTS. Unidentified calcareous sponge.

DISTRIBUTION. The species is known only from the type locality — Moorea, Society Islands, French Polynesia.

\section{KEY TO THE “ONYCOCARIS PROFUNDA"- SPECIES GROUP}

1.Distal margin of telson sharply produced O. temiri Marin, 2005

- Distal margin of telson rounded, not sharply produced . 2

2. Proximal antennular segment with long sharp distolateral tooth reaching to the upper distal margin of the next segment O. rudolfi sp.n.

- Proximal antennular segment with small blunt distolateral tooth non-reaching to the middle length of the next segment O. profunda Bruce, 1985

Onycocaris cf. amakusensis Fujino et Miyake, 1969 Fig. 14.

Onycocaris amakusensis Fujino et Miyake, 1969: 143, figs. 6, 8a-c, 9a-c [type locality: Japan]. — Marin, 2007: 219, figs. 2-4.

MATERIAL EXAMINED. 1 male (pcl. $1.4 \mathrm{~mm}$ ), UF: Arthropoda: 15675 (BMOO-2993), Pacific Ocean, French Polynesia, Society Islands, Moorea, off E of Opunohu pass, 17.4817, 149.8558, MIB_040, at Shark Feeding buoy, outer reef slope, sandy and reef slope, from rubble, 17-18 meters, coll. S. McKeon, J. Moore, G. Paulay, 16.10.2008. (15675 DNA subsample) (color photo - http:/ /biocode.berkeley.edu/cgi/biocode_img_query? enlarge $=4444+$ 4444+1009+0962).

REMARKS. The specimen is probably a juvenile because of its very small size. Nevertheless, morpho- logically it clearly refers to the group of species showing small toothless rostrum (Figs 14a, $b$ ), pereiopods II slightly unequal in size but mostly similar in shape (Fig. 14d,e) bearing large distolateral tooth on ischium, produced distolateral angle of merus, carpus with distally produced angle and simple not subspatulated fingers of pereiopod II. This group includes $O$. amakusensis, O. bocki, O. callyspongiae, O. oligodentata, O. stradbrockei and O. zarenkovi sp.n. By the absence of additional submarginal teeth (also lacking in $O$. callyspongiae and $O$. zarenkovi sp.n.) and serrated ventral margin of the accessory unguis (Fig. 14f) of of pereiopod III (smooth in O. stradbrockei and O. bocki, and also serrated in $O$. oligodentata) and well-marked basal denticles of dactylus of pereiopod III (Fig. 14f) (feebly developed in $O$. oligodentata), the examined specimen is mostly related to $O$. amakusensis.

COLORATION. Generally body and appendages translucent; carapace, abdomen and telson with small white chromatophores.

DISTRIBUTION. Possibly, the first record of $O$. amakusensis from Moorea, Society Islands, French Polynesia; the species is also known from the western Indian Ocean, tropical coasts of Japan, Vietnam and the Great Barrier Reef of Australia [Fujino, Miyake, 1969; Bruce, 1976, 2010a, b; Fransen, 1994; De Grave, 2001; Marin, 2012].

ACKNOWLEDGEMENTS. Author is very thankful to Dr. Gustav Paulay (UF) and Dr. Arthur Anker for the invitation to the University of Florida and the assistance during processing of the Museum collection. The sampling of the material in French Polynesia was accomplished within the project BioCode. The preparation of the paper was also partly supported by grants of the President of the Russian Federation \# MK-4481.2014.4 and the Russian Foundation for Basic Research (RFFI projects \#\# 15-04-05125_a and 15-34-20863_mol_a_ved).

\section{References}

Anker A., Marin I.N. 2006. New records and species of Alpheidae (Crustacea: Decapoda) from Vietnam. Part I. Genus Salmoneus Holthuis, 1955 // Raffles Bulletin of Zoology. Vol.54. No.2. P.295-319

Anker A., Marin I. 2007. Athanas anatidactylus n. sp., a new alpheid shrimp associated with crinoids in the tropical western Pacific (Crustacea: Decapoda) // Zoological Studies. Vol.46. No.2. P.162-167.

Anker A., Poddoubtchenko D., Marin I. 2006. On the presence of the alpheid shrimp genus Bermudacaris Anker and Iliffe, 2000 (Crustacea: Decapoda: Caridea) in the Pacific Ocean, with description of a new species from Vietnam // Journal of Natural History. Vol.40. No.27-28. P.1675-1686.

Bruce A.J. 1976. A synopsis of the pontoniid shrimp fauna of Central East Africa // J. Mar. Biol. Ass. India. Vol.16. No.2. P.462-490.

Bruce A.J. 1985. Decapod Crustacea: Pontoniinae (MUSORSTOM II) // Resultats des Ñampagnes MUSORSTOM, I et II - Philippines $(1876,1980)$. Memoirs du Muséum National d'Histoire Naturelle, série A, Zoologie. Vol.133. P.229-260.

Bruce A.J. 1990. Recent additions to the pontoniine shrimp fauna of Australia // The Beagle: Records of the Museums and Art Galleries of the Northern Territory. Vol.7. No.2. P.9-20. 


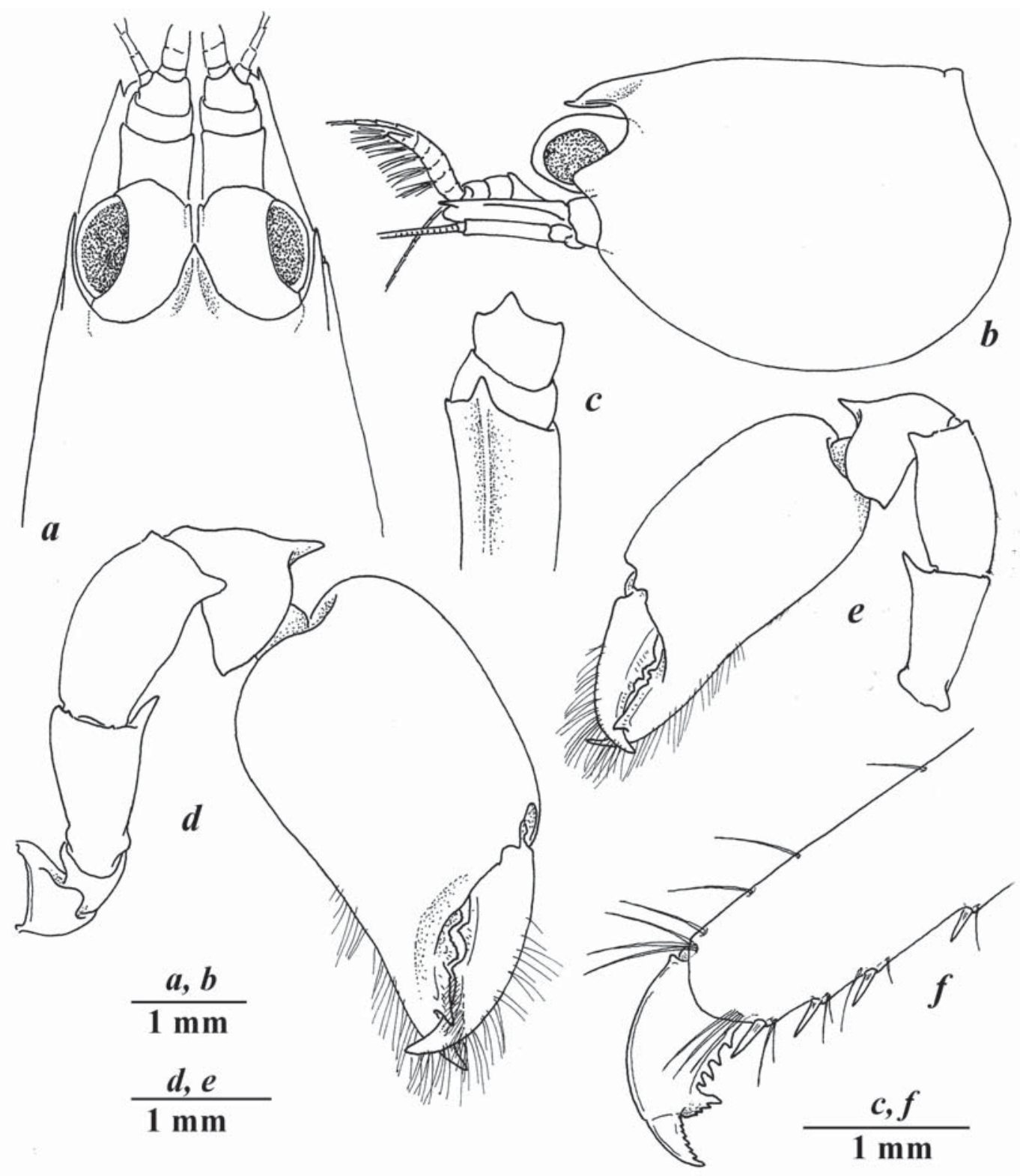

Fig. 14. Onycocaris cf. amakusensis Fujino et Miyake, 1969, male (UF: Arthropoda: 1567), Moorea: $a$ - front of carapace, dorsal view; $b$ - carapace, lateral view; $c$ - antennular peduncle; $d$ - major pereiopod II; $e$ - minor pereiopod II; $f$ - distal propodus and dactylus of pereiopod III

Рис. 14. Onycocaris cf. amakusensis Fujino et Miyake, 1969, самец (UF: Arthropoda: 1567), Муреа: $а$ - передняя часть карапакса, вид сверху; $b$ - карапакс, вид сбоку; $c$ - антеннулярный стебелек; $d$ - большая переопода II; $e$ - меньшая переопода II; $f$ - дистальная часть проподуса и дактидус переопод III.

Bruce A.J. 2010a. Pontoniine shrimps (Crustacea: Decapoda: Palaemonidae) from the CReefs 2009 Heron Island Expedition, with a review of the Heron Island pontoniine fauna // Zootaxa. Vol.2541. P.50-68.

Bruce A.J. 2010b. More pontoniine shrimps (Crustacea: Decapoda: Palaemonidae) from the CReefs 2009 Heron Island Expedition // Zootaxa. Vol.2604. P.20-36

Bruce A.J. 2011a. Notes on some Indo-Pacific Pontoniinae, XLVIII. Onycocaris nieli sp. nov., a new pontoniine shrimp from Heron Island, Queensland // Crustaceana. Vol.84. No.3. P.319-330.

Bruce A.J. 2011b. Notes on some Indo-Pacific Pontoniinae, XLIX. Onycocaris balssi sp. nov., from northern Australia, with the designation of $O$. fujinoi sp. nov. // Crustaceana. Vol.84. P.477-490.
Bruce A.J. 2012. Onycocaris longirostris Bruce, 1980 (Crustacea: Decapoda: Pontoniinae), new to the Australian fauna // Zootaxa. Vol.3299. P.61-65.

Fransen C.H.J.M. 1994. Marine palaemonoid shrimps of the Netherlands Seychelles Expedition 1992-1993 // Zoologische Verhandelingen. Vol.297. P.85-152.

Fujino T., Miyake S. 1969. Studies on the genus Onycocaris with descriptions of five new species (Crustacea, Decapoda, Palaemonidae) // Journal of the Faculty of Agriculture, Kyushu University. Vol.15. P.403-448.

De Grave S. 2001. Biogeography of Indo-Pacific Pontoniinae (Crustacea, Decapoda): a PAE analysis // Journal of Biogeography. Vol.28. P.1239-1253. 
Ďuriš Z., Horka I., Marin I. 2008. Periclimenes sulcatus sp. nov., a new pontoniine shrimp (Crustacea: Decapoda: Palaemonidae) from Vietnam // Zootaxa. Vol.1860. P.35-50.

Dworschak P., Marin I., Anker A. 2006. A new species of Naushonia Kingsley, 1897 (Decapoda: Thalassinidea: Laomediidae) from Vietnam and the Philippines with notes on the genus Espeleonaushonia Juarrero, Martínez-Iglesías, 1997 // Zootaxa. Vol.1372. P.1-16.

Hayashi K. 2003. Shrimps and lobsters from Japan (127). Family Palaemonidae, subfamily Pontoniinae - Genus Onycocaris // Aquabiology. Vol.144. P.21-26.

Komai T., Itou I. 2012. A new species of the pontoniine shrimp genus Onycocaris Nobili, 1904 (Crustacea: Decapoda: Caridea: Palaemonidae) from Sagami Bay, central Japan // Zootaxa. Vol.3440. P.50-62.

Koo H.Y., Kim W. 2003. First report of palaemonid shrimp Onycocaris callyspongiae (Decapoda: Caridea: Palaemonidae) from Korea // Korean Journal of Systematic Zoology. Vol.19. P.251255.

Marin I. 2005. Pontoniine shrimps (Crustacea, Decapoda, Pontoniinae) from Viet Nam. Onycocaris temiri sp. n., a new sponge- associated shrimp from Nha Trang Bay // Arthropoda Selecta. Vol.13. No.3. P.113-122.

Marin I. 2007. Pontoniine shrimps (Caridea: Palaemonidae, Pontoniinae) inhabiting boring sponges (Demospongia: Porifera) in Vietnam with description of three new species // Zoologische Mededelingen. Vol.81. P.217-240.

Marin I.N. 2012. New records and associations of pontoniine shrimps (Crustacea: Decapoda: Caridea: Palaemonidae: Pontoniinae) from the Nhatrang Bay, Vietnam; with taxonomic remarks on some species from the Indo-West Pacific region // Britayev T.A., Pavlov D.S. (eds.). Benthic fauna of the Bay of Nhatrang, Southern Vietnam. Moscow: KMK Sci. Press. Vol.2. P.345-405.

Marin I.N., Savinkin O.V. 2007. Further records and preliminary list of pontoniine (Caridea: Palaemonidae: Pontoniinae) and hymenocerid (Caridea: Hymenoceridae) shrimps from Nhatrang Bay // Britayev T.A., Pavlov D.S. (eds). Benthic fauna of the Bay of Nhatrang, Southern Vietnam. Moscow: KMK Sci. Press. Vol.1. P.175-208.

Responsible editor V.A. Spiridonov 